pp. $43-50$

\author{
Adam KORZENIOWSKI \\ ORCID 0000-0002-5259-0220 \\ Uniwersytet Pedagogiczny im. KEN \\ w Krakowie
}

\title{
Dziecięcy repertuar muzyczny w procesie elementarnej edukacji muzycznej
}

\begin{abstract}
Children's musical repertoire in the process of elementary music education
The aim of the article is the initial/preliminary systematization of the types of children's musical repertoire. The definition of the repertoire and its forms were analyzed and interpreted. Based on the analysis of the literature on the subject, the categories of children's repertoire were described in correlation with musical activities. An attempt was also made to describe the structure of the children's musical repertoire.
\end{abstract}

Keywords: musical repertoire, musical activity, child

Słowa kluczowe: repertuar muzyczny, aktywność muzyczna, dziecko

\section{Wprowadzenie}

Zapowiedź, że Czytelnik znajdzie w artykule jeden z podstawowych problemów elementarnej edukacji muzycznej, jakim jest dziecięcy repertuar muzyczny, podyktowana jest kilkoma względami.

Primo, obszar muzycznej aktywności obejmuje wiele funkcji spotykanych w codziennym życiu (dziecka), choć nie zawsze są to funkcje o podłożu muzycznym. To zrozumiałe. Rodzi to potrzebę przeanalizowania, które z owych funkcji będą kierowały tę specyficzną aktywność ku różnorodnym aktywnościom i czynnościom edukacji muzycznej.

Secundo, początkowe ustrukturyzowanie rodzajów aktywności, z jakimi możemy się zetknąć w obrębie dziecięcego repertuaru muzycznego, wyznacza stosunkowo szerokie ramy treściowe. Stąd zamiar autora kontynuowania szczegółowej analizy dziecięcego repertuaru muzycznego w kolejnych publikacjach. 
Tertio, możliwości realizowania utworów i wytworów muzycznego repertuaru dziecka - zarówno w procesie kształcenia, jak i wychowania - są ściśle powiązane $z$ rozwojem dziecka. Zasadne wydaje się wyodrębnienie etapów jego rozwoju i edukacji oraz połączenie tychże pod względem możliwości i zakresów wielorakich działań muzycznych dziecka.

\section{Repertuar — wstępna systematyzacja}

Podejmując próbę wstępnego opisania dziecięcego repertuaru, odwołajmy się na początek do definicji samego słowa repertuar.

Władysław Kopaliński (1989, s. 438) w Stowniku wyrazów obcych i zwrotów obcojęzycznych podaje, że „repertuar to komplet, zestaw utworów (sztuk, ról) albo umiejętności, które może zaprezentować (wykonać) jakiś zespół, wykonawca (wirtuoz, śpiewak, aktor) ... itd."

Znacząca dla podjętych rozważań jest zacytowana definicja, jako że dziecko jest niezwykłym wykonawcą. Specyficzna jest również dziecięca kreatywność, zwłaszcza w kontekście improwizacji ruchem, głosem bądź na instrumencie. Odkrywamy wtedy np. małego śpiewaka i aktora.

Czy dziecięcy repertuar to zestaw utworów, a może komplet?

Zapewne nie, gdyż wspomniana improwizacja komplet ten za każdym razem może dopełnić.

Zamiarem tej wypowiedzi jest raczej wskazanie, z czego m.in. składa się repertuar muzyczny dziecka. Będą to na pewno utwory, do których pojawi się ruch, albo te zaśpiewane, albo te zagrane. W dalszej kolejności uwaga zostanie zwrócona na ten obszar, który odpowiadać będzie repertuarowi do słuchania, i wreszcie ten, który powstaje dzięki specyficznej aktywności muzycznej, jaką jest tworzenie.

Powyższa zapowiedź rodzajów repertuaru prowadzi nas wprost do podstawowych rodzajów aktywności muzycznych, jeszcze kilkanaście lat temu nazywanych formami wychowania muzycznego. Zwróciła na ten aspekt uwagę m.in. wybitna polska pedagog prof. Zofia Burowska ${ }^{1}$, której dokonania wspominał w krakowskiej Akademii Muzycznej podczas konferencji „In memoriam” prof. Jerzy Kurcz ${ }^{2}$

${ }^{1}$ Prof. dr Zofia Burowska - muzykolog, pedagog muzyki; w latach 1972-1978 prodziekan, a w latach 1978-1981 dziekan Wydziału Wychowania Muzycznego w Akademii Muzycznej w Krakowie; kierownik Katedry Wychowania Muzycznego w latach 1980-1987. Twórczyni zespołu naukowego, w którego skład przez cały okres aktywności naukowej wchodzili prof. dr Jerzy Kurcz oraz dr Andrzej Wilk. Zespół stworzył koncepcję programowo-metodyczną nauczania muzyki w szkolnictwie ogólnokształcącym, zwaną Krakowską Koncepcją Wychowania Muzycznego.

${ }^{2}$ Prof. dr Jerzy Kurcz - współtwórca Krakowskiej Koncepcji Wychowania Muzycznego; w latach 1978-1981 prodziekan, a od 1996 do 1999 r. dziekan Wydziału Edukacji Muzycznej w Akademii Muzycznej w Krakowie, pedagog muzyki, dydaktyk, chórmistrz, długoletni kierownik 
(„Wychowanie Muzyczne”, 2014): „Zofia Burowska jako doświadczony pedagog i wnikliwy badacz rzeczywistości edukacyjnej wielkie znaczenie przypisywała działaniom o charakterze integracyjnym w procesie nauczania muzyki - dotyczyło to treści międzyprzedmiotowych, ale przede wszystkim form aktywności mu zycznej w nauczaniu-uczeniu się muzyki”.

Podobnie Andrzej Wilk ${ }^{3}$ (2004, s. 26), wybitny polski pedagog muzyki, podkreślał: „Istnieją też rzeczywiste możliwości intensyfikacji (akceleracji) rozwoju słuchu muzycznego, poczucia rytmu, słuchu harmonicznego, pamięci muzycznej poprzez zastosowanie odpowiednich metod kształcenia słuchu, uwzględniając wiele rodzajów aktywności muzycznej oraz czynności wychowania muzycznego".

Potrzebne wydaje się wstępne systematyzowanie dziecięcego repertuaru muzycznego oparte właśnie na podstawowych aktywnościach muzycznych (Przychodzińska, 1969; Burowska, 1976).

Umotywowany powyżej kierunek postępowania decyduje o tym, iż repertuar (zestaw utworów) może pojawić się z różnych powodów i w różnych okolicznościach. Niejednokrotnie bywa on zainspirowany. W muzyce to bardzo ważne zagadnienie, inspiracja $\mathrm{w}$ tej dziedzinie sztuki stała się bowiem stylem, kiedy to w języku kompozytorskim pojawiło się nawiązywanie do poezji symbolistów, a częściowo również do malarstwa impresjonistycznego, z wyjątkowym wyczuleniem na brzmienie jako samoistny środek wyrazu. (Encyklopedia muzyki, 2001; hasło impresjonizm).

\section{Inspirowanie dzieci do działań muzycznych}

Postawmy zatem pytanie, kto może zainspirować dziecko do czynności muzycznej?

Na początku źródłem inspiracji jest środowisko rodzinne, później przedszkolne, szkolne, rówieśnicze, kulturowe etc. To tam pojawiają się osoby, sytuacje, zdarzenia, które w sposób szczególny skłaniają dziecko do bycia aktywnym również muzycznie. Być może jest to założenie idealistyczne, ale na pewno ze wszech miar pożądane. Inspirują rodzice, rodzeństwo, nauczyciel, rówieśnicy, nie sposób wymienić wszystkich. Inspiruje wreszcie sama muzyka, której obecność w życiu człowieka — także dziecka — jest faktem egzystencjalnie niezaprzeczalnym.

\footnotetext{
Katedry Badań Muzyczno-Edukacyjnych w AM. Prowadzi m.in. badania w zakresie pedagogiki muzyki, pedeutologii oraz nauk o sztuce.

${ }^{3}$ Dr Andrzej Wilk - pedagog muzyki, doktor nauk humanistycznych, współtwórca Krakowskiej Koncepcji Wychowania Muzycznego. Interesuje się problemami z pogranicza pedagogiki, estetyki, psychologii muzycznej oraz pedeutologii. Od wielu lat prowadzi badania dotyczące kształtu i skuteczności Krakowskiej Koncepcji Wychowania Muzycznego dzieci i młodzieży.
} 
Dziecięcy repertuar może być zadany, zasugerowany albo zai mprowi zow any. Niemal za każdym razem towarzyszy mu wspomniana inspiracja.

Warto w tym miejscu zapytać, kto może zadać lub zasugerować dziecku ów repertuar.

Romualda Ławrowska w książce Rytm, muzyka, taniec w edukacji (2005) podkreśla znaczącą rolę muzyki, a tym samym informacji, symboli i kodów w niej zawartych. To elementy muzyki i swoiste uniwersum, jakie tworzą, są bodźcem do zaistnienia tworów muzycznych, składających się później na repertuar. Jak już wspomniano, wśród inspiratorów — „zadających” — są, a nade wszystko powinni być, najbliżsi. To śpiewająca mama, nucący ojciec, chwalące się nowymi przygodami muzycznymi rodzeństwo czy wreszcie babcia z sentymentem odtwarzająca melodie młodości. Oni wszyscy stają się pierwszą społecznością zapraszającą dziecko do świata muzyki. Sugestia, że tak można, a przy tym różnorodność form przekazu, sprawiają, że mały człowiek sam podejmuje próby „akustycznego zaistnienia” we wspomnianej społeczności. Jest to kolejne oblicze przytoczonego wcześniej „niezaprzeczalnego egzystencjalnie faktu”. Akceptacja wszelkich podejmowanych przez dziecko prób muzycznych w tym obszarze dopełnia w sposób zasadniczy proces pojawiania się dziecięcego repertuaru muzycznego.

Kolejny etap tworzenia dziecięcego repertuaru muzycznego wiąże się $\mathrm{z}$ formami opieki, wychowania i edukacji. Etapy pojawiania się w życiu dziecka umiejętności muzycznych będą związane $z$ osobami, które sprawują opiekę nad nim $\mathrm{w}$ domu, $\mathrm{w}$ żłobku, potem przedszkolu i wreszcie podczas pobytu w szkole. W tym miejscu pojawia się wizja, trudna do wyobrażenia i równie trudna do zaakceptowania, że dziecku podczas pobytu w żłobku, przedszkolu czy szkole mogłaby nie towarzyszyć muzyka. Oby ten fakt nigdy nie zaistniał.

Warto pamiętać, że bogactwo melodii, ekspresji, kolorystyki, rozmaitości rytmicznych i agogicznych, będących elementami muzyki, jest gwarantem i determinantem ogólnego rozwoju człowieka, a zwłaszcza dziecka.

Przytoczmy fragment teorii Eliasa Edwina Gordona:

Ci, którzy dużo wiedzą o rozwoju dziecka, żartują czasami, że chcieliby umrzeć jako małe dzieci, ale najpóźniej jak tylko byłoby to możliwe. Zdają sobie bowiem sprawę, że możliwości uczenia się nigdy nie są większe niż w chwili narodzin. Wobec tego, przyjmując, że najważniejszym okresem dla uczenia się jest czas od pierwszych chwil po urodzeniu (a może jeszcze przed tym faktem) do ukończenia trzeciego roku życia, należy kierować dzieckiem tak, aby odbierało nieustrukturowane, nieformalne oddziaływania. Kolejny pod względem ważności okres to lata między trzecim a piątym rokiem - okres oddziaływań już ustrukturowanych, ale wciąż nieformalnych, realizowanych przez dom rodzinny lub przedszkole. To, czego dziecko uczy się podczas pierwszych pięciu lat życia, tworzy podstawę dla całej późniejszej edukacji, która tradycyjnie rozpoczyna się wraz z przekroczeniem progu przedszkolnej czy szkolnej „zerówki”. Im wcześniej dziecko uzyska tę podstawę, tym więcej skorzysta z późniejszej edukacji i odwrotnie - im później tego dokona, tym gorsze będą dalsze efekty. Po raz drugi nie powtórzy się 
okazja do nadrobienia tych zaniedbań, a nauczanie w takiej sytuacji będzie miało charakter jedynie wyrównawczy, a nie wzbogacający (Gordon, 1997, s. 5).

Warto zaznaczyć, że podobne twierdzenia stawia prof. Maria Manturzewska, wybitna i zasłużona postać oraz niekwestionowany autorytet $\mathrm{w}$ dziedzinie psychologii muzyki (Manturzewska, Kamińska, 1990)

Z kolei Wiesława Aleksandra Sacher w książce Pedagogika muzyki pisze:

Z badań psychologów wynika, że wszystkie dzieci posiadają uzdolnienia muzyczne, choć o zróżnicowanym poziomie. Umożliwiają one nabywanie umiejętności muzycznych i twórczych w stopniu pozwalającym na doświadczenie estetyczne w kontakcie z różnymi rodzajami muzyki. Ze względu na opisany przez psychologów muzyki rozwój zdolności muzycznych stabilizujących się w wieku 10-11 lat kształcenie muzyczne powinno być najintensywniejsze szczególnie w przedszkolu i w pierwszym etapie edukacji szkolnej (Sacher, (2012, s. 168).

\section{Typy repertuarów}

Problem podstawowy to odpowiedź na pytanie, w jakim stopniu dziecięcy repertuar odpowiada podstawowym aktywnościom muzycznym?

Owe aktywności to:

- ruch przy muzyce lub do niej;

- spiew;

— gra na instrumentach;

- tworzenie;

- słuchanie.

Typy repertuarów - usystematyzowane według aktywności muzycznych — będą zatem następujące:

— ruchow y - jest efektem percepcji, a w dalszej kolejności reakcji kinestetycznych naszego organizmu, które pojawią się wtedy, gdy słyszymy muzykę (ruch przy muzyce), ale również wtedy, kiedy nasze reakcje są wynikiem świadomej realizacji elementów muzycznych (ruch do muzyki).

Niezwykle trafnie, ale zarazem pięknie i uniwersalnie, opisał ruch i taniec Włodzimierz Tomaszewski:

Kontakt człowieka ze światem odbywa się poprzez ciało ludzkie. Ciało w połączeniu z podstawowymi atrybutami człowieczej „materii”; ruchem i rytmem — zrodziło taniec. Narodzinom tańca towarzyszył śpiew i okrzyki bądź inne źródła akustyczne uruchamiane przez ciało. Tak powstała „trójjedyna choreia” - specyficznie ludzki sposób ekspresji, zwany kilka tysięcy lat później sztuką (Tomaszewski, 1991, s. 7).

Te wstępne rozważania na temat repertuaru ruchowego, jego znaczenia i funkcji w życiu dziecka można podsumować następująco: „Bez względu na ro- 
dzaj stosowanej metody [w edukacji], jeśli zawiera ona elementy ruchu stymulowanego muzyką, będzie przynosić dziecku wielostronne korzyści” (Sacher, 2012, s. 208);

- wokalny - najogólniej rzecz ujmując, powstaje on podczas wydobywania głosu ${ }^{4}$. Wstępnie możemy założyć, że efektem wydobywania głosu jest wokalizowanie, mówienie, śpiewanie itp.. Wiążą się z tym procesem gatunki wokalne, które są efektem głosowej aktywności. Są to nucanki (określenie autora), śpiewanki i piosenki, ale również różne umiejętności fonacyjne i artykulacyjne $\mathrm{z}$ obszaru mowy. Pewną podpowiedzią w systematyzowaniu takiego repertuaru będą niemal wszystkie zagadnienia związane $\mathrm{z}$ rozwojem mowy dziecka;

— instrumentalny — powstaje na ogół wówczas, gdy korzystamy z jakiegoś przedmiotu/instrumentu, na którym lub z którego możemy wydobyć dźwięk. Nie można w tym miejscu pominąć tak zwanego body drums, gdyż to właśnie nasze ciało i jego właściwości dają nam niezwykłą możliwość wykorzystania go jako instrumentu. Z kolei przedmioty, te z najbliższego otoczenia, które niejednokrotnie stają się również instrumentami, pomagają dziecku $\mathrm{w}$ tak zwanej organizacji przestrzeni akustycznej wokół niego. Przykładów zaobserwowanych $\mathrm{w}$ codziennym życiu $\mathrm{z}$ dziećmi można tutaj przytoczyć wiele. Warto również podkreślić, że na początku niemal wszystkie formy poznane i wykonane ruchem oraz głosem przez dziecko, są jednymi z pierwszych, które dziecko pragnie odtworzyć na tak zwanych instrumentach. Kolejność etapów rozwoju dziecięcej gry omówiona zostanie w kolejnych publikacjach.

Swoistym credo mogą być w tym miejscu słowa Doroty Szwarcman (2008), która w artykule Bardziej głuche ucho pisze: „[...] żywe muzykowanie, prowadzone przez osobę kompetentną może być dla dzieci i młodzieży wielką atrakcją, nie mówiąc o tym, że to świetna szkoła zachowań społecznych i kooperacji”;

- do słuchania

Niejednokrotnie można spotkać się z opinią, że dziecko może słuchać tylko przez krótki czas, wybiórczo, itd. Jest w tym dużo prawdy, albowiem taki stan dyktuje natura dziecka, poziom jego rozwoju fizycznego, społecznego, emocjonalnego. Fakt ten staje się przez swoją specyfikę i złożoność swoistym wyzwaniem dla wszystkich, którzy proponują dziecku słuchanie - czegoś i kogoś.

Zanim dane zjawisko dźwiękowe stanie się dla dziecka częścią repertuaru do słuchania, niejednokrotnie jest pojedynczym impulsem dźwiękowym albo przypadkowym zbiorem dźwięków z otoczenia. Analiza słuchowa - zarówno przypadkowa, jak i przeprowadzona według merytorycznych zasad, najczęściej realizowanych przez rodziców, opiekunów czy nauczycieli i wychowawców - pobudza wyobraźnię. Ta z kolei pomaga w tworzeniu wyobrażeń słuchowych, którym niemal zawsze towarzyszą określone emocje. Cały ten

\footnotetext{
${ }^{4} \mathrm{O}$ sposobach operowania głosem i wielu zagadnieniach z tym związanych w kolejnej publikacji.
} 
proces buduje w nas pewien obraz, twór dźwiękowy, otoczony aurą ekspresji, z którą dane zjawisko akustyczne przeżywamy. Tak oto powstaje coś, do czego chcemy wracać, coś, co chcemy zapamiętać, coś, co chcemy jeszcze nieraz przeżyć - nie zawsze tak samo. W słuchaczu rodzi się pragnienie, aby ów twór mieć w swoim (dostępnym) repertuarze;

- wytworzony

Definicja tworzenia mówi, że jest to „powodowanie powstawania czegoś”, oraz że tworzyć to „być sprawcą rzeczy, której przedtem nie było, ustanawiać, organizować, konstytuować". W tego typu repertuarze spodziewać się powinniśmy nowych utworów, na nowo ustanowionych i zorganizowanych, których sprawcą jest dziecko. Trudno negować taki proces. Powstaje jednak pytanie, na ile rządzi nim przypadek, a na ile racjonalne postępowanie dziecka. Większość odpowiedzi wskaże zapewne zależność od stopnia i poziomu rozwoju umysłowego oraz fizycznego i będzie to prawda. W definicji zacytowanej czytamy również, że "tworzyć to również komponować, pisać utwór muzyczny” (Stownik jezyka polskiego, 1995, t. III, s. 518) W komponowaniu czy pisaniu utworu muzycznego ważne są pewne reguły, których znajomość w tym procesie jest nieodzowna. Dziecko - zważywszy na fakt jego „wchodzenia w otaczający go świat" - nie miało jeszcze okazji, aby wspomniane reguły poznać, a tym bardziej zastosować. Jest jednak w dziecku pewna naturalna zdolność, przez którą staje się ono wybitnym wręcz twórcą. To dziecięca improwizacja. Wymienia się najczéściej improwizację swobodna i inspirowana/kierowaną. Gdy źródłem bodźców do improwizacji jest muzyka, niejednokrotnie górę bierze spontaniczność i specyficzny, ale jakże piękny, dziecięcy entuzjazm. W tej drugiej - kierowanej - to najczęściej człowiek, rodzic, nauczyciel, rówieśnik, muzyka... etc. pobudza do improwizacji.

Dopełnieniem tego niech będzie cytat z Encyklopedii muzyki (2001; hasło improwizacja): „Improwizacja to działalność artystyczna, w której akt twórczy pokrywa się z wykonaniem jednocześnie powstającego utworu".

Dziecięcy repertuar muzyczny jest zatem zbiorem aktów twórczych dziecka. Jest również pewnym zestawem utworów, w których dominować będzie odtwórczość. Jest wreszcie niezwykle obszerną propozycją edukacyjną i wychowawczą, którą my, dorośli - wychowawcy, pedagodzy, twórcy - proponujemy dziecku do wykonania lub, jak kto woli, do zrealizowania. Warto zatem będzie skupić się w przyszłości nad wyborem tych propozycji, a także ich wartościami i celami. 


\section{Bibliografia}

Burowska, Z. (1976). Wspótczesne systemy i koncepcje edukacji muzycznej, Warszawa: WSiP.

Burowska, Z. (1980). Stuchanie i tworzenie muzyki w szkole, Warszawa: WSiP.

Burowska, Z. (1991). Wprowadzenie w kulture muzyczna. Warszawa: WSiP.

Encyklopedia muzyki (2001). Red. A. Chodkowski. Warszawa: PWN. [Hasła: impresjonizm, improwizacja].

Gordon, E. E. (1997). Umuzykalnienie niemowlat $i$ małych dzieci. Kraków: Zamiast Korepetycji; https://www.fundacjakreatywnejedukacji.org/teoria-profesora-edwina-e-gordona/

Kalarus, A. (2018). Muzyczne działania percepcyjno-zabawowo-twórcze jako formy aktywności prewencyjnej wobec szkolnego stresu uczniów szkót podstawowych. Kraków: Wyd. AM.

Kopaliński, W. (1989). Stownik wyrazów obcych i zwrotów obcojęzycznych. Wyd. 19. Warszawa: Wiedza Powszechna.

Ławrowska, R. (2005). Rytm, muzyka, taniec w edukacji. Podręcznik dla studentów i nauczycieli pedagogiki przedszkolnej $i$ wczesnoszkolnej. Kraków: ZamKor.

Manturzewska, M., Kamińska, B. (1990). Rozwój muzyczny człowieka. W: M. Manturzewska, H. Kotarska (red.), Wybrane zagadnienia z psychologii muzyki. Warszawa: WSiP.

Przychodzińska, M. (1969). Muzyka $i$ wychowanie. Warszawa: Nasza Księgarnia.

Sacher, W. A. (2012). Pedagogika muzyki. Kraków: Impuls.

Stownik jezyka polskiego (1995). Red. M. Szymczak. Wyd. 1 scalone. T. III. Warszawa: PWN.

Szwarcman, D. (2008). Bardziej gluche ucho. „Polityka”, nr 6 (2640) (9 II).

Tomaszewski, W. (1991). Cztowiek tańczacy. Warszawa: WSiP.

Wilk, A. (2004). Problemat kompetencji muzyczno-pedagogicznych studentów pedagogiki wczesnoszkolnej $i$ nauczycieli klas poczatkowych szkoły podstawowej w świetle przeprowadzonych badan w latach 1992-1999. Kraków: Wyd. Naukowe AP.

„Wychowanie Muzyczne”, 5 (2014). Dwumiesięcznik, listopad-grudzień, http://www.wychmuz.pl/userfiles/2014/2014\%20inne/WM_2014_5-.pdf 